\title{
CORRUPTION IN THE EUROPEAN UNION AND THE RESPONSIBILITY OF EUROPEAN INSTITUTIONS
}

\section{Liviu RADU}

\author{
Liviu RADU \\ Lecturer, Department of Public Administration \\ and Management, Faculty of Political, Administrative \\ and Communication Sciences, \\ Babeş-Bolyai University, Cluj-Napoca, Romania \\ Tel.: 0040-722-260.091 \\ E-mail: liviu.radu@fspac.ro
}

\begin{abstract}
Corruption is one of the most concerning problems of the contemporary societies. It is especially a serious issue for countries in transition to democracy. Romania is one of the cases where corruption seems to be a problem that has no solutions. Much emphasis was placed on the improvement of the functioning of justice, and some positive signs seemed to appear in the last few years. But justice is like a surgeon who is cutting but is hardly putting something instead. Therefore, I am advocating that an emphasis should be placed on the development of a sound civil service that will ensure an improved ethical conduct in the public service.
\end{abstract}

Keywords: corruption, Romania, administrative reforms, culture, merit system. 


\section{Introduction}

Corruption is considered to be one of the most concerning problems for modern societies. In the last several years, even countries that were previously immune to this phenomenon, like Finland, encountered several problems that were considered unethical (European Commission, 2014b). As Klitgaard stated:

'Not so many years ago, corruption flourished in countries we now call 'developed'and indeed there is evidence that some forms of corrupt behavior are today on the rise in the most economically and politically 'advanced' nations. Corruption scandals in recent years have led to changes at the highest level of the government in Holland, West Germany, Great Britain, Israel, Japan and the United States' (Klitgaard, 1998, p. 10).

The matter is a lot more serious in new European Union member states, especially in Romania and Bulgaria or in the possible future member states or partners of EU. All of the above mentioned countries are listed with high levels of corruption in Transparency International Corruption Perception Index (the FYR of Macedonia - rank 64/score 45, Bulgaria and Romania - 69/43, Serbia - 78/41, Bosnia and Hertzegovina - 80/39, Moldova - 103/35, Ukraine - 142/26) (Transparency International Corruption Perception Index, 2014). For European Union member states, the European Commission Report on Corruption from 2014 (European Commission, 2014a) states that the Eurobarometer survey undertaken in 2013 confirmed the Transparency International data for most of the EU countries (Transparency International Corruption Perception Index, 2014).

Specialists and scholars in this field are rather pessimistic concerning the possibility to curb corruption worldwide. An analysis of the Corruption Perception Index for the last ten years indicates that the vast majority of the countries had decreased their CPI score and only a few improved it. In 2014, 69\% of the surveyed countries scored below 50 out of 100 . An interesting figure shows that among the G20 countries, presumably the most developed in the world, $58 \%$ had scores below 50 (Transparency International Corruption Perception Index, 2014). The European Union Report on Corruption states that the Eurobarometer survey conducted in 2013 showed a high level of concern among European citizens related to corruption (European Commission, 2014a). Thus, '... three quarters of respondents (76\%) think that corruption is widespread in their own country' (Transparency International Corruption Perception Index, 2014) and 'a quarter of Europeans (26\%), compared with $29 \%$ showed by the 2011 Euro Barometer, consider that they are personally affected by corruption in their daily lives'. However, there are important differences among countries. In some of them (Denmark, Sweden, Finland and Luxembourg), the perception is positive, while in others (Germany, the Netherlands, Belgium, Estonia and France) the general perception is negative but with very few individual experiences (Transparency International Corruption Perception Index, 2014). Thus, the report is revealing two facts: the increasing concern of the European citizens related to widespread corruption and the significant differences that exist between various groups of states. This second aspect 
will be approached more extensively below. However, a brief analysis of the nature of the public service in some of the above mentioned countries is leading to one obvious conclusion: the level of corruption is directly connected with the quality of the public administration, i.e. of the civil service. Hence the paper will try to answer to the following questions:

1. Are cultural and historical antecedents important in the ethical profile of a certain country?

2. Is the implementation of the merit system a decisive step in reducing corruption?

3. Should the European Commission promote merit systems and ethical climate in public administration in new member states?

4. What possible sources of legitimacy may be claimed by these European institutions?

The subject is important, especially for some of the prospective new member states (Ukraine, Moldova, Georgia).

\section{Is curbing corruption possible?}

According to Rothstein and Uslaner (2005), corruption seems to be very 'sticky'; that is to say, it is extremely resilient. This pessimistic opinion is fueled by the observation that in the last decades there were only two examples of countries that successfully curbed the phenomenon of corruption: Singapore and Hong Kong. To make the prospective for future even less optimistic, these are small countries and, especially in the case of Singapore, the methods used to combat corruption were highly controversial. In other words, democracy seems to be less appropriate for fighting against unethical behavior. But this opinion which is supported by some critics of democracy is strongly contested by Carl J. Friedrich who is mentioning several examples of monarchies or totalitarian countries severely affected by corruption $(1999, \mathrm{p} .17)$. So rather the two countries are exceptions among the less democratic countries. But if the models offered by Singapore and Hong Kong cannot be adopted at full scale, some of the institutions and policies that were developed in these countries may receive our attention. See for example the excellent case study presented in their book by Klitgaard et al. (2000) about the process of eliminating corruption from the Hong Kong police. Also, letting aside the allegations related to abuses, the strategy adopted by Singapore is worth to be taken into consideration. According to Quah (1999), the anti-corruption strategy was based on two pillars: first, reducing the incentive for corruption by raising salaries and improving working conditions and in the same time increasing the penalties for corruption; and second, reducing the opportunities for corruption mainly through managerial measures. Other three lessons from the experience of Singapore that Quah is pointing out are: a strong and determined political leadership, a comprehensive approach, and an incorruptible anti-corruption agency (Quah, 1999).

The situation in the field of corruption in countries with recently established democracies (Latin American countries, Central and Eastern European countries), and 
even in relatively old European Union member states such as Italy and Greece is strengthening this conclusion: corruption is a phenomenon difficult to combat. In the case of Italy, after the relative success of the 'clean hand' operation in early 1990s, things became apparently worst in recent years (della Porta and Vannucci, 2012).

However, maybe we are looking in the wrong direction. If it is true that in recent decades there were very few successful stories in combating corruption, we may find such 'stories' in the $18^{\text {th }}$ and $19^{\text {th }}$ century. Sweden and the other Scandinavian states were characterized at that time, according to Rothstein, by a high level of corruption: 'However, contrary to what is often believed, during the $18^{\text {th }}$ and $19^{\text {th }}$ century, the Scandinavian states were by today's standards thoroughly corrupt' (Rothstein, 2011). The same is true for France, Great Britain or USA. In France the selling of public offices was a common practice and the monarchy was the major actor in this process. Eighteenth century France was a country dominated by privileged casts and their opposition to reforms was one of the major causes that led to the French revolution. Britain in the eighteenth and the nineteenth centuries was '(...) a corrupt, clientelistic oligarchy (...)' (Kam, 2015, p. 2). Carl Friedrich is stating that: 'In fact the system that Walpole built is perhaps the most striking instance of corruption functioning effectively to transform a political system and establish a new one' (Friedrich, 1999, p. 20). And previous to Pendleton Act (1883), the American politico-administrative system was labeled as the 'spoils system'.

The explanation Rothstein is giving for Sweden is a process that he is describing as an indirect 'Big Bang' in the state institutional settings. The process described by Rothstein firmly established the 'merit system' in Sweden's public administration (Rothstein, 2011, pp. 19-23). Even if it is difficult to prove a direct connection between the establishment of the merit system and the diminishment of corruption, the assumption that the creation of a professional, stable and politically neutral bureaucracy had an important influence, both in the modernization of the respective countries and in reducing corruption, may be valid to a large extent.

According to many authors, what happened in the second part of the $19^{\text {th }}$ century in many Western countries was a transition from a system with 'limited access order' to one with 'open access order' (Rothstein, 2011; North, Wallis and Weingast, 2009). Other authors are speaking about 'universalistic vs. particularistic' systems (Mungiu-Pippidi, 2006) or 'achievement vs. 'ascription", concepts proposed by Parsons and Shils apud Peters (2010).

North, Wallis and Weingast (2009) are describing the transfer from 'limited access order' to 'open access order' in three countries: Great Britain, France and US. In their view, this process consisted in changes in political and economic settings to allow the participation of the entire society in the respective activities, process that took place to a large extent in the second part of the $19^{\text {th }}$ century. It is my strong belief, together with Bo Rothstein, that one more measure should be added to explain the modernization of most of the Western states, the democratization and the reduction of corruption: the establishment of the merit system. As mentioned above, Rothstein is arguing 
that the promotion of a number of measures that established in a relative short period of time (1860-1875) the merit system in Sweden were equivalent with an 'indirect bigbang', that is a major push, upon the Swedish political and administrative establishment (Rothstein, 2011, p. 22).

Analyzing the case of other Western countries we may find that the promotion of meritocracy in their administrative systems was previous to the extensive development of the economy and the significant reduction of corruption. The reforms that introduced the merit system were usually fueled either by a prominent political figure, by some elite groups or by a major military defeat. It was the decisive reign of Friedrich Wilhelm I that transformed dramatically a society that was previously preoccupied by luxury and architectural grandeur. The reforms started by the 'King Soldier' resulted in the establishment of a Weberian type of administration in Prussia. New reforms were implemented after the defeat in the war against Napoleon in 1806 (Radu, 2014).

In the case of France, the turmoil of the revolution produced chaos in the already inefficient and corrupt administration inherited from the Ancient Regime. The thorough reforms that Napoleon undertook between 1800 and 1808 established a centralized, hierarchical and highly efficient public administration.

In Great Britain, the merit system was introduced after the Northcote-Trevelyan report in 1854. As Friedrich is describing:

'In fact, the process by which the British pull themselves out of the morass of corruption (...) and developed what is, in the opinion of many, the most thoroughly honest public service ever organized is little short of miraculous. It shows that pathological phenomena are not necessarily destined to go from bad to worse and the corrective for them is often quite readily at hand' (Friedrich, 1999, pp. 21-22).

Therefore, one conclusion may be that the first step and a compulsory one for the countries having problems with corruption should be the establishment of a sound and functional 'merit system'. This may be referred at by what Bo Rothstein is naming as 'Big Bang', a major change in the institutional arrangements of a state that may lead to a significant change in the attitudes of public officials and of the society in general. There are a lot of debates related to the poor quality of the political class. In almost all the countries in the world, including in the most developed and democratic ones the people's trust in politicians is lower every year. Whether this image is correct or not exceeds the aim of this paper. However, in Romania increasing the quality of the political class, which is the replacement of 'bad politicians' with better ones, is a topic that appears frequently in the public debates. But enough arguments can be brought that this is an almost impossible task. I will only mention the numerous extremist parties that exist in most of the developed Western countries. On the other hand, a professional and politically neutral bureaucracy presents a number of advantages. First, it is the possibility to select, by well-designed admission and promotion procedures, the most qualified and honest persons especially for managerial positions. Second, civil servants have a strong incentive to act professionally and be- 
have honestly: they have an enormous benefit - the perspective of a lifelong career and consequently a major penalty if they lose their position because of wrong doing.

\section{Cultural aspects related to corruption}

As I mentioned above, to some extent the situation is similar in many other countries that are going through the process of democratization: slow and partial implementation of public administration reforms and a relatively high level of corruption. One question arises: why institutions that proved to be successful in most of the developed countries are ineffective in countries that are facing transition to democracy (Rothstein, 2011; Mungiu Pippidi, 2006)? One answer may be related to cultural differences. But then, we should discuss about the different behaviors of countries belonging to same or close cultural traditions. Why other countries from South-East Asia did not have results similar to Singapore and Hong Kong? Why is Italy so different from France or Spain? And why is southern Italy so different from the northern part of the country? Historical, cultural and geographical context led to different administrative patterns even among the Western countries. Both Germany (Prussia) and France developed classical Weberian bureaucracies. Yet, there are important differences between the two systems, for instance from the point of view of the importance of the central government in establishing policies at local level. Also, despite the efforts to reform their administrative systems according to the Weberian principles, Anglo-Saxon countries were always very far from the level of bureaucratization of the European continental states (Peters, 2010). In case of England, Strayer is pointing at a distinctive characteristic: the country did not face 'centrifugal tendencies - provinces that attempted to separate from the main body of the country' and consequently did not need to create a strong administration to control the territory (Strayer, 1972).

Many of the Central and Eastern European countries had a different historical evolution. Unlike the Western European kingdoms, where the hereditary monarchies secured the succession to the throne in the vast majority of the cases, in countries like Hungary and Poland this rule was not in place. The result was a number of wars for succession that weakened the respective states until their political disappearance. Hungary in 1541 and Poland in 1795 disappeared from the political map of Europe. The political instability and the short existence of the state (especially in the case of Hungary) prevented the development of national administration in these two countries. Hungary and some territories from Poland were integrated in the Habsburg Empire and in this way the Weberian type of administration, but of Austrian origin, was implemented in the respective territories. Transylvania which is now part of Romania was occupied by the Habsburg Empire in 1699 and faced the same fate (Radu, 2015b). But after the end of WW2 the administration of both countries and of Transylvania (now part of Romania) was shaped after the principles of the communist regimes.

In conclusion, culture does influence the administrative pattern of a certain country and consequently the level of corruption. But, is it decisive? Is it like an eternal 
punishment for some sins from the past that some countries cannot rid of? Was it some cultural specificity that allowed the mentioned Western country to successfully reduce corruption in the second half of the $19^{\text {th }}$ century? Is the incapacity of some states to eradicate corruption of cultural nature? Rothstein is stating that '(...) if practice of corruption clearly has cultural traits, it should not be seen as culturally determined' (Rothstein, 2011, p. 6). The fact that countries with the same culture may have very different levels of corruption, according to Transparency International Corruption Perception Index, and that in the rankings of Transparency International the first places are occupied by countries with very different cultural backgrounds may lead to the conclusion that culture has influence on the level of corruption, but it is not a decisive factor.

\section{The case of Romania}

From a historical point of view, Romania inherited two major administrative patterns. Transylvania became part of the Habsburg Empire in 1699 and the Austrians imposed their Weberian type of administration. The two principalities outside of the Carpathian Mountains, Valachia and Moldavia, fell under the domination of the Ottoman Empire and from 1711 were ruled by princes appointed from Istanbul. The vast majority of the candidates originated from a neighborhood of Istanbul called Phanar, inhabited by people of Greek origin. That period that lasted for more than a century is known as the Phanariote regime and is associated in the Romanian public conscience as well as in the opinion of many of our historians with the origin of our endemic corruption. Historical facts are supporting this image. Candidates for the thrones of the two countries had to pay enormous bribes to Istanbul to obtain the offices. After they were crowned, they tried to recover their initial 'investment'. The methods used for this purpose was selling of public offices and spoiling the population. The level of corruption was very high and the poverty increased significantly (Radu, 2015b). However, some remarks should be made. First, as mentioned above, selling public offices was a common practice in Western European countries in that historical period. Second, some of the Phanariote princes were persons with exceptional education and they tried to implement reforms that were advanced for that period.

'Indeed, the Phanariote century (1711-1821) may be labeled as the 'century of reforms', because during over one hundred years all the fields of the social life - taxation policy, agriculture, administration, justice, religion and culture were subject of a huge reconstruction that ultimately aimed the establishment of public order and modernization (...). The reform policies were focusing especially on administration and justice' (Constantiniu, 1998, pp. 181-185).

Why these reforms were not successful? One answer is that the two countries were often war theaters, but the most important reason was that the reigns of Phanariote princes were very short. During approximately one century, there were 36 mandates in Valachia and 34 in Moldavia. Therefore, it was impossible for the above mentioned 
reforms to produce long lasting results. The Phanariote regimes ended in 1821 and the two principalities were unified in 1859. The new country gained its independence from the Turkish Empire in 1877. Especially after unification, a process of massive reforms started in an attempt to modernize the country according to Western standards. Public administration was one of the major targets of these reforms that were influenced mainly by the French administrative system. It was a fairly centralized model with a relatively low level of local and regional autonomy. But the new institutions and laws created in the second part of the $19^{\text {th }}$ century were, as one of the former ministers of education labeled them, 'forms without substance'. Even if Romania adopted the Western, Weberian type of administration, in theory, the traditions inherited from the past were still influencing to a large extent the functioning of the state institutions. Statistical data are not available, but the belletristic literature abounds in references to the corrupt practices of the political and administrative establishment. After 1918, a difficult task was to integrate the new territories achieved after WWI (the surface of the country almost doubled and $28 \%$ of the population belonged to minorities) (Djuvara, 2006, p. 233). A law for administrative unification was issued in 1925 but it was changed almost every year due to the political instability. Previously, in 1923, the first Civil Service Statute was enacted. But the feeble Romanian democratic regime was brought to an end in 1938, and for 52 years the country was subject of authoritarian and totalitarian regimes, including the communist one.

The Romanian communist regime was one of the harshest inside the communist bloc. First, a system based on terror was installed in the late 1940s and during the 1950s. Second, after liberalization (the late 1970s and the 1980s) there was a period of 'milder' suppression of any kind of opposition or even of any kind of opinion that was different from the official ones. As a result, after the change of regime in 1989 Romania did not have consistent elites that could support democratic values. In addition, the violent nature of the Revolution gave legitimacy to the second and third layer of the communist party (many Romanians considered that they escaped us of Ceaușescu). But in the context of this paper it is important to mention that the disastrous economic and social policies that Ceaușescu promoted led to a very poor performance of the Romanian economy. In addition, to emphasize on his alleged independence he decided to pay in advance the country's national debt. It was a chase for hard currency through extensive exports and many times products were sold under their production costs. Thus, starting with the early 1980s a huge shortage of goods and basic services occurred in the country. Consequently, the population suffered and was forced to find ways to survive. Goods were procured on the black market or through underground channels; bribes were needed to receive public services, including medical ones. In communist Romania informal relations were more important than money and 'Kent cigarettes were the hard currency of the country' (Boia, 2001, pp. 140-143). Since it was not possible to obtain products on the official market, steeling, especially from the state, was considered to be legitimate. Moreover, the function of the economy was based on similar practices: to obtain raw materials a 
producer often had to bribe the supplier. In addition, it was the corruption of the party leadership that enforced in the mentality of the population the idea that the only way of surviving was to be part of the system.

This was, in short, the heritage the communist regime left in Romania. As Djuvara stated: '(...) a regime (...) in which theft, not only from the state but also from your neighbors, ended up to be considered legitimate, due to the permanent lack of goods and the examples of corruption coming from the leadership, inevitably left important marks in mentalities and behaviors' (Djuvara, 2006, p. 258). As mentioned above, the change of the regime in 1990 did not produce the necessary change in values, mentalities and practices. The members of the communist establishment that took the power after the Revolution continued to conduct the public institutions and policies in the way they were accustomed in the previous regime. Although some important institutions like the two chambers of the Parliament, an independent National Bank or autonomous local authorities were established in the early years, the pace of reforms was very slow in the first decade after the Revolution. The start of the negotiation for the accession in Euro Atlantic organizations, NATO and especially European Union, had as a result an acceleration of the rhythm of reforms.

Romania started the negotiations for accession to the EU in 1998. Analyzing the evolution of the Romanian legislation we can state that the rhythm of the reforms increased significantly after the starting of the negotiations. That is to say that Romania witnessed, between 1998 and 2007, a process that can be characterized as being close to what Rothstein designed as 'Bing Bang'. Especially due to the pressure made by the European Commission and other international donors, a lot of reform measures were taken in all the fields of activity. One major target of reforms was the Romanian public administration. Areas like local public administration and local public finance, civil service statute and the Senior Civil Service and the decision making process at the level of the central government were addressed by thorough reforms. Even if the results were not spectacular, the fact that the EU accession was a success proved that the reforms produced, to a certain degree, positive effects.

'Romania was perceived to have made enough progress in its reforms to consolidate its democratic systems, institute the rule of law, acknowledge respect for human rights, commit to personal freedom of expression, and implement a functioning free-market economy to be admitted to the EU on $1^{\text {st }}$ of January 2007' (Ioniță, 2008, p. 172).

Unfortunately, the pace of reforms in Romanian public administration slowed down significantly after the completion of the accession process. Reports of the international organizations or public opinion surveys show that the perception related to the performances of the Romanian administration and the level of corruption in the country is negative to a large extent. That is to say, the progresses made previous to 2007 were more or less annulled afterwards (Radu, 2015a).

According to Mungiu-Pippidi, it is probably about 'particularism' vs. 'universalism', that is 'particularism' - a mode of social organization characterized by the regu- 
lar distribution of public goods on a non-universalistic basis that mirrors the vicious distribution of power within such societies' (Mungiu-Pippidi, 2006, p. 87) vs. equal distribution of the benefits based on laws that are universally applicable. Or in other words, a system that is dominated by informal rules and one in which formal rules have the dominant role. Or it is a different understanding of the term public values as they are defined by Bozeman: 'Public values are those providing normative consensus about a) rights, benefits, and prerogatives to which citizens should or (should not) be entitled; b) obligations of the citizens to society, the state, and one another; and c) the principles on which government and policies should be based' (Bozeman, 2007). That is to say, Romania adopted the 'universalistic' model or the Western understanding of the public values under the pressures of the European institutions and returned to the 'particularistic' pattern afterwards.

Another model that can be employed to understand the situation of Romania and probably of other former communist countries is James C. Scott's 'machine politics'. In his opinion, 'deference patterns have weakened considerably in a period of rapid socioeconomic change (...). Competition among leaders for [electoral] support, coupled with the predominance of narrow, parochial loyalties, will encourage the widespread use of concrete, short-run, material inducements to secure cooperation' (Scott, 1999, p. 279). It is almost a perfect image of today's Romania. The discipline enforced by the communist party (corruption was tolerated only to a certain degree) collapsed and a number of local or regional cliques occurred competing for power. A part of the business environment is financing electoral campaigns, usually illegally, and is receiving public contracts after elections are won. Electoral bribes, money and products are offered to ordinary citizens in exchange for votes.

In short, the following elements are characteristic for corruption in Romania:

- The distortion and manipulation of electoral campaigns;

- Extensive politicization of the public administration through political appointment and partisan influence of the decision-making processes;

- Abusive and partisan use of the public funds;

- Abuse of power (use of public institution in the personal interest of the politicians);

- Systemic corruption; and

- State capture. ${ }^{1}$

\section{Conclusion}

From the five 'learnings' Quah is mentioning for Singapore, one was accomplished to a large extent in Romania, that is an incorruptible anti-corruption agency. The National Anti-Corruption Directorate has started to prosecute important corruption cases and the justice had convicted a number of important political figures. Due to this

1 Due to space limitation these aspects will be detailed in an extended version of the paper. 
fact, a second requirement is partially met: the reduction of the incentive for corruption by making it more costly. But the other three are missing almost entirely. That is to say, Romania does not have yet a comprehensive approach to curb corruption that will address also the issue of reducing opportunities through managerial measures. And above all, Romania is lacking 'a strong and determined political leadership' to promote anti-corruption measures. The establishment of professional and politically neutral civil service, which is a prerequisite for the accomplishment of the other two conditions, is not on the agenda of Romanian political parties. But from 2007 Romania does have a kind of political leadership that may have the determination to take the necessary measures to curb the phenomenon of corruption. Only that, so far, the European Commission seems to be less interested to be involved directly in combating corruption in member states. The approach that European institutions were related to curbing corruption and to public administration reforms in general was superficial and often inappropriate. After making considerable efforts in the pre-accession period to support the reform measures, they decided to take their hands off and refrain only to monitoring. It seems that European officials paid little attention to the lack of capacity of the Romanian political class to further promote the reforms. The reports on the 'Cooperation and verification mechanism' issued yearly by the European Commission are referring mainly to issues related to justice, the role of public administration in curbing corruption being almost ignored. As Dwivedi stated: 'Ethnocentrism and ignorance in the West have continued to overshadow the need to appreciate the importance of local culture, traditions, and style of governance. It is their style of governance and the administrative culture that reflect the distinctiveness and complexity of various national identities, realities, and cultural diversities. These factors should be taken into consideration when imposing public service reforms and other conditionalities' (Dwivedi, 2005, p. 33).

In an attempt to answer the four questions addressed at the beginning of the paper I will express the following opinions:

1. The cultural traditions have a certain influence on the way public administration is functioning in certain countries, and consequently on the level of corruption. Nevertheless, this should not be an obstacle in developing a sound and honest public service. Only that, in designing a reform project, cultural traits and local conditions should be carefully analyzed.

2. Even if it is difficult to prove a direct link between the establishment of the merit system and the significant diminishment of corruption, the fact that the least corrupt countries are those with advanced administrative systems may validate this theory to a large extent.

3. Yes, European institutions should develop legislative provisions and institutional structures to promote the merit system and ethical conduct among member states in the same way they are enforcing European regulations in other fields.

4. Not only the legitimacy but also the obligation of European institutions to adopt the above mentioned measures may be firmly established by referring at the prin- 
cipal - agent model. The most important European principal, the European citizen and tax-payer is entitled to pretend from the agents, which are the European institutions, to ensure a good quality of the expenditure of the European funds. A lot of these funds were wasted because of the poor functioning of the public administration in certain countries. The reluctance of some of the old European member states related to an acquis communnitaire in the field of public administration is well known but some minimum set of generally accepted principles and rules can be identified:

- 'A limited set of rules related to human resource management mainly concerning the observance of the principles of the merit system;

- A limited set of rules related to budgetary and financial mechanisms;

- A limited set of rules related to the quality of public expenditures; and

- A limited set of rules related to policy formulation' (Radu, 2015a).

\section{References:}

1. Boia, L., Romania: Borderland of Europe, London: Reaction Book Ltd, 2001.

2. Bozeman, B., Public Values and Public Interest. Counterbalancing Economic Individualism, Washington: Georgetown University Press, 2007.

3. Constantiniu, F., O istorie sinceră a poporului român (An Honest History of the Romanian People), Bucharest: Editura Univers Enciclopedic, 1998.

4. della Porta, D. and Vannucci, A., The Secret Order of Corruption. An Institutional Approach, Burlington: Ashgate Publishing Limited, 2012.

5. Djuvara, N., O scurtă istorie a românilor povestită celor tineri (A Short History of Romanians Told to the Younsters), Bucharest: Humanitas, 2006.

6. Dwivedi, O.P., 'Administrative Culture and Values: Approaches', in Jabbra, J.G. and Dwivedi, O.P. (eds.), Administrative Culture in a Global Context, Ottawa: de Sitter Publications, 2005, pp. 19-36.

7. European Commission, 'Special Eurobarometer 397. Corruption', 2014a, [Online] available at http://ec.europa.eu/public_opinion/archives/ebs/ebs_397_en.pdf, accessed on June, 15, 2015.

8. European Commission, 'Report from the Commission to the Council and the European Parliament. EU Anti-Corruption Report, 2014b, [Online] available at http://ec.europa. eu/dgs/home-affairs/e-library/documents/policies/organized-crime-and-human-traf ficking/corruption/docs/acr_2014_en.pdf, accessed on April 29, 2015.

9. Friedrich, C.J., 'Corruption Concepts in Historical Perspective', in Heidenheimer, A.J., Johnston, M. and LeVine, V.T. (eds.), Political Corruption. A Handbook, London: Transaction Publishers, 1999, pp. 15-24.

10. Gardiner, J.A. and Lyman, T.R., 'The Logic of Corruption Control', in Heidenheimer, A.J., Johnston, M. and LeVine, V.T. (eds.), Political Corruption. A Handbook, London: Transaction Publishers, 1999, pp. 827-840.

11. Ioniță, S., 'Unfinished Modernization: Public Administration Reform in Post-Communist Romania', in Killian, J. and Eklund, N. (eds.), Handbook of Administrative Reform. An International Perspective, New York: Taylor \& Francis Group, 2008, pp. 159-176. 
12. Kam, C, 'Partisanship, Enfranchisement, and the Political Economy of Electioneering in the United Kingdom, 1820-1906', Research paper, University of British Columbia, 2015, [Online] available at http://www.lse.ac.uk/government/research/resgroups/ PSPE/pdf/Kam.pdf, accessed on April 29, 2015.

13. Klitgaard, R., Controlling Corruption, Los Angeles: California University Press, 1998.

14. Klitgaard, R., Mac-Lean Abaroa, R. and Parris, H.L., Corrupt Cities. A Practical Guide to Cure and Prevention, Oakland: ICS Press, 2000.

15. Mungiu-Pippidi, A., 'Corruption: Diagnoses and Treatment', 2006, Journal of Democracy, vol. 17, no. 3, pp. 86-99.

16. North, D.C, Wallis, J.J. and Weingast, B.R, Violence and Social Orders. A Conceptual Framework for Interpreting Recorded Human History, New York: Cambridge University Press, 2009.

17. Peters, G.B, The Politics of Bureaucracy. An Introduction to Comparative Public Administration, New York: Routledge, Taylor \& Francis Group, 2010.

18. Quah, J.S.T., 'Singapore's Experience in Curbing Corruption', in Heidenheimer, A.J., Johnston, M. and LeVine, V.T. (eds.), Political Corruption. A Handbook, London: Transaction Publishers, 1999, pp. 841-854.

19. Radu, L., Relațiile politico-administrative / Political-administrative relations /, Cluj-Napoca: Accent, 2014.

20. Radu, L., 'How to Develop Sustainable Public Administration Reforms', 2015a, Transylvanian Review of Administrative Sciences, no. 44E, pp.180-195.

21. Radu, L., 'Cultural Aspects Related to Romanian Public Administration in the Context of Integration in European Union', paper presented at the International Conference: History, Culture, Citizenship in the European Union, University of Pitești, Romania, May 8-9, $2015 b$.

22. Rothstein, B. and Uslaner, E., 'All for All: Equality, Corruption, and Social Trust', 2005, World Politics, vol. 58, no. 1, pp. 41-72.

23. Rothstein, B., 'Anti-Corruption: The Indirect "Big-Bang" Approach', 2011, Review of International Political Economy, vol. 18, no. 2, pp. 228-250.

24. Scott, J.C, 'Corruption, Machine Politics and Political Change', in Heidenheimer, A.J., Johnston, M. and LeVine, V.T. (eds.), Political Corruption. A Handbook, London, Transaction Publishers, 1999, pp. 275-286.

25. Strayer, J.R., On the Medieval Origin of the Modern States, Princeton, NJ: Princeton University Press, 1972.

26. Transparency International, 'Corruption Perception Index: 2014', 2014, [Online] available at https://www.transparency.org/cpi2014/results, accessed on June, 15, 2015. 